УДК 621. 391

https://doi.org/10.47533/2020.1606-146X.60

A. N. *AZHEN, Z. M. ABDIAKHMETOVA, B. K. ALIMBAYEVA, M. K. BEKBAYEVA

\author{
Al-Farabi Kazakh National University, Almaty, Kazakhstan, \\ e-mail:azhen_ayazhan@mail.ru,zukhra.abdiakhmetova@gmail.com, \\ abaggi@mail.ru,maya.bekbayeva@gmail.com
}

\title{
CREATION OF AN INFORMATION SYSTEM FOR DETERMINING THE SYMPTOMS OF HUMAN DISEASES
}

The article provides for the creation of an information system that identifies the symptoms of the disease. The neural system was used to diagnose the disease. The neural network consists of an input layer, 3 hidden layers and an output layer. The neural system was fully functional and gave very good results. The telegram bot was created to make it easier for users to use. The telegram bot meets all the requirements of the information system and is available to everyone.

Key words: artificial intelligence, diagnostics, information system, telegram Bot API, testing.

Introduction. Artificial intelligence in the world.

Australian researchers examined the symptoms of 1,217 medical reports from 36 diagnoses available on the internet and found that only $36 \%$ of them were correct, compared to $58 \%$ of the top ten diagnoses. Sites that use "artificial intelligence techniques" to diagnose and take into account the user's demographic data have successfully coped with this task.

Systems that use "artificial intelligence" for diagnosis and take into account demographic data turned out to be the most accurate and correct diagnosis, $46 \%$ of the results are correct [1].

The first virtual hospital for coronavirus patients is being tested in New South Wales, Australia. If a patient is diagnosed with the initial stage of the disease, he is not immediately taken to the hospital, but supplied with a control device that is attached to the wrist and placed in home quarantine. The device transmits the main indicators of the work of the heart and lungs to the virtual department of the hospital. With the help of artificial intelligence, doctors monitor indicators on the internet and can ask for hospitalization if a patient gets worse [2].

The potential of artificial intelligence in medicine is much greater, you just need to be able to use it correctly.

Artificial intelligence in Kazakhstan.

Recently launched online health diagnostics using artificial intelligence - iMedHub. The patient is diagnosed remotely, which is especially important during the quarantine regime. In Kazakhstan, lung disease is still diagnosed with an accuracy of $87 \%$.

According to the developers, iMedHub can be used in pulmonology, mammography, neuroradiology, histology, ophthalmology, cardiology and dermatology.

How to make a diagnosis online?

Doctors study X-rays from the PACS archive and then study the neural network. After a few seconds, the program will display its analysis. Physicians can view medical records and analyzes in electronic medical records. Users can access the program through computers and mobile applications [3].

*Адрес для переписки. E-mail: azhen_ayazhan@mail.ru 
Research methods. The neural network consists of an input layer, 3 hidden layers and an output layer (Figure 1).

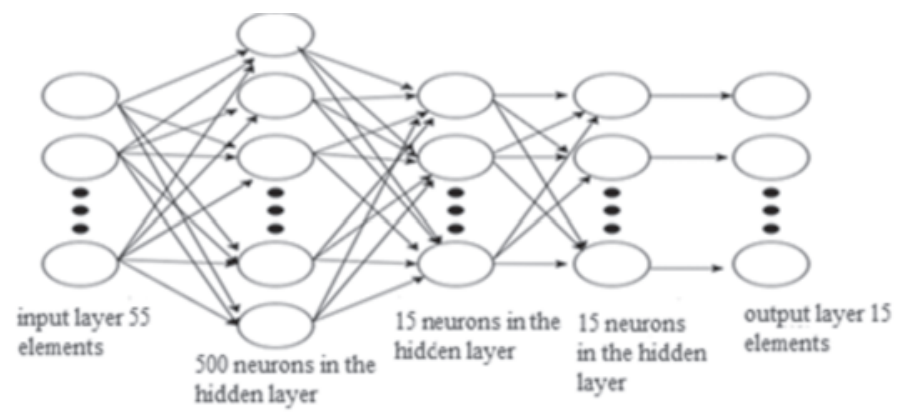

Figure 1 - Neural network layers

The first hidden layer contains 500 neurons, and the activation function is called Relu [4].

$$
\sigma(x)=\max \{0, x\}
$$

The second hidden layer contains 15 neurons, and the activation function is called softmax.

$$
\sigma(x)_{i}=\frac{e^{x_{i}}}{\sum_{j=1}^{k} e^{x_{j}}}
$$

The third has 15 hidden neurons and an activation function.

$$
\sigma(x)=\left\{\begin{array}{l}
1, x>0.001 \\
0, \text { else }
\end{array}\right.
$$

The first two inner layers are fully connected, while the third inner layer is connected only to the neurons in front of it (Figure 2, 3).

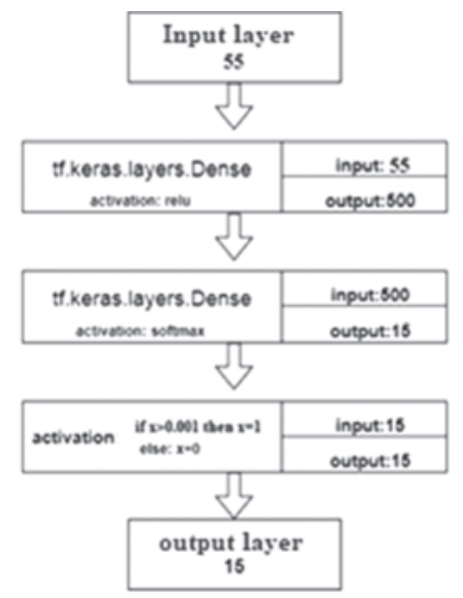

Figure 2 - Connecting layers 

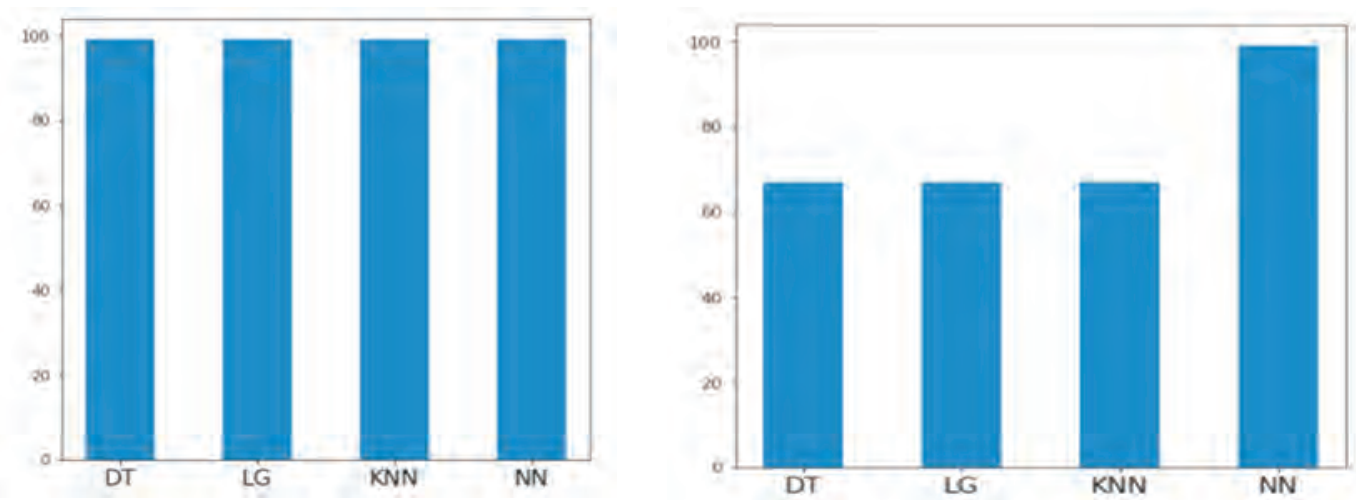

Figure 3 - Comparing machine learning models

For one source of disease, all classification algorithms have the same correct result by $99 \%[5,6]$. In patients with multiple sources of the disease, only the neural system was able to give a good result (Figure 4).

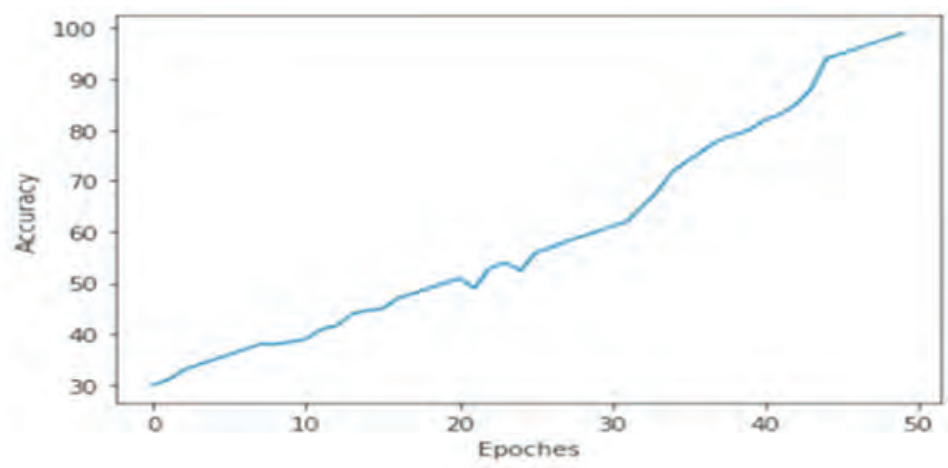

Figure 4 - Neural network training

The neural system was fully functional and gave very good results. It should be noted that all algorithms were developed in a source with the same symptoms of 850 patients and tested in a source with 300 patients. The neural system was fully functional and have very good results. It should be noted that all algorithms were developed in a source with the same symptoms of 850 patients and tested in a source with 300 patients $[7,8]$.

To make it easier for people to use, we create a telegram bot and used the trained model in the bot.

The telegram bot was chosen as the information system. Because it meets all the tasks of the information system and is available to everyone. The bot we created is one of the most useful.

The bot was written in Python. To write the bot, the Telegram Bot API was used.

The principle of operation of our bot is a vector $n=55$ for the patient's symptoms. A member of the symptomatic vector is denoted 1 , and the missing member is denoted 0 and is sent to the neural system, where the neural system makes a decision depending on the 
vector [9]. It consists of $n=15$ vectors and 1 and 0 . Outputs a diagnosis of the number of the element having 1 in the vector (Figure 5).

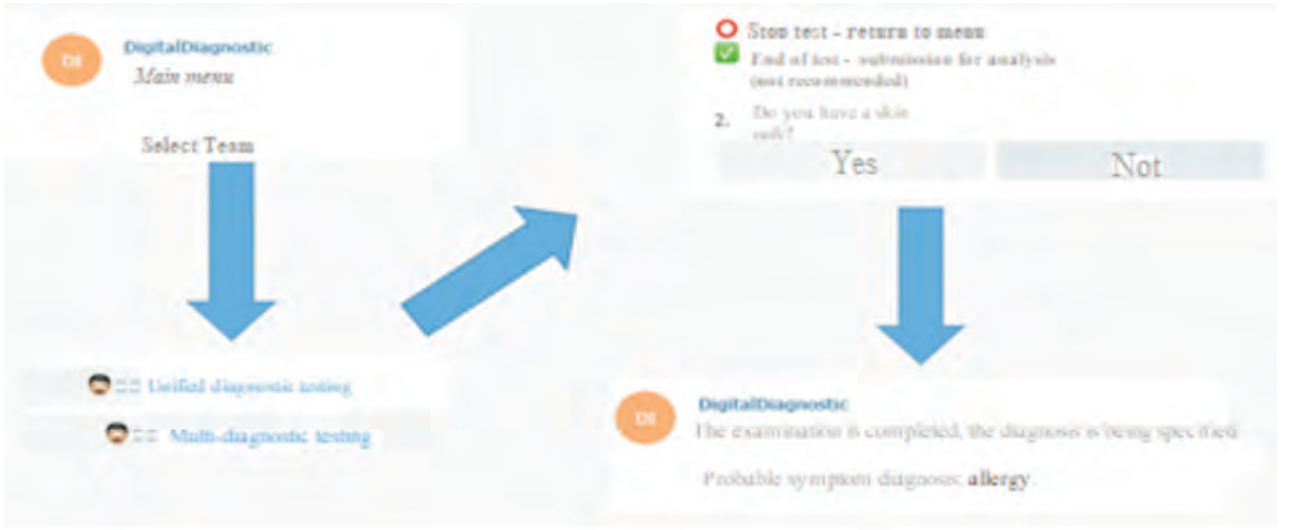

Figure 5 - Bot's current result

When opening a bot, two types of diagnostics are offered. These are "Single Diagnostic Testing" and "Multiple Diagnostic Testing" [10].

In the first mode, the bot will ask you if you have 55 symptoms.

In the second mode, the bot will ask you if you have 55 symptoms and the number of questions related to symptoms will decrease. In contrast to the first mode, several diseases can be detected in this mode. By answering the questions, you will receive a prognostic diagnosis and information about your diagnosis and the institution that treats it. Thus, with the help of our bot, people can find a prognostic diagnosis and immediately contact the right doctor (Figure 6).

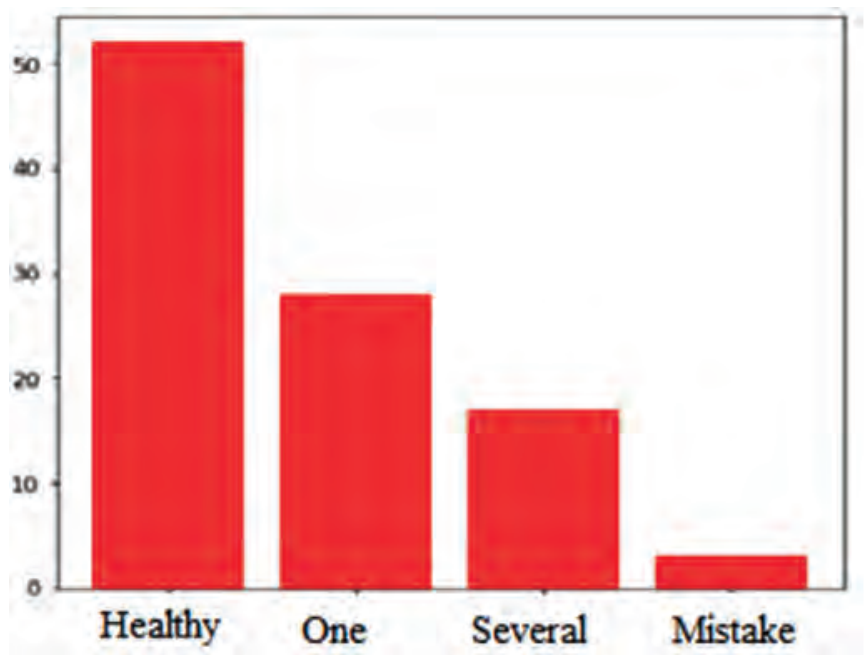

Figure 6 - Current result of the information system 
After the implementation of the information system, a survey was conducted of the first 100 people who used it $[11,12]$. In the course of the survey, it turned out that the information system correctly diagnosed 97 people (Figure 7).

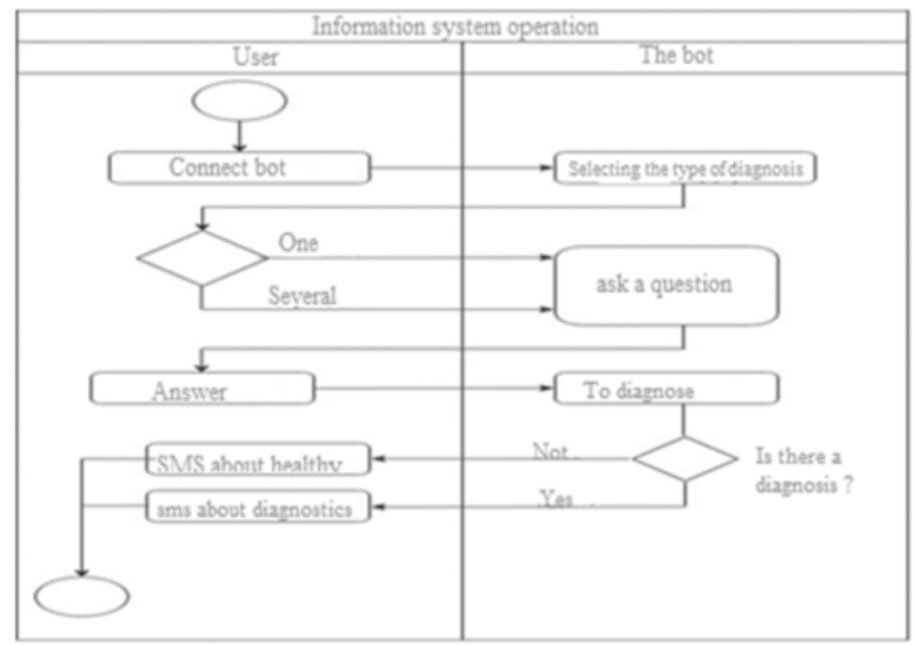

Figure 7 - Use of information systems Activity diagram

Conclusions. We have a fully functioning information system available to all citizens of Kazakhstan by telegram. The main advantage of our information system is that you can use it for free [13].

Self-diagnostic capability using online resources and medical applications. simplify the work of doctors with digital technology. As mentioned above, the information system works through a neural system and has an accuracy of $99 \%$. The neural system is a major advantage over all other classification algorithms at the source of multiple diseases. Our system can be used in any medical center.

The digitalization of medicine in Kazakhstan is not sufficiently developed. Therefore, the system we have created is one of the first information systems in the field of medicine in Kazakhstan. If a lot of work is done in this direction and development of the information system, it will be very useful for people. In developed countries such as the USA, Germany, Japan, such IS are developing and are in great demand.

However, a IS will never replace a doctor. Therefore, it is best to see a doctor rather than treat yourself with a IS diagnosis [14].

\section{REFERENCES}

1 Arthur D. Little (2016) Succeeding with digital health. Winning offerings and digital transformation. Available at: http://www.adlittle.com//sites/default/files/viewpoints/ADL_2016_Succeeding_With_Digital_Health.pdf (accessed 01 October 2017).

2 Ash, Timur, "Dynamic Node Creation in Backpropagation Networks", Department of Computer Science and Engineering, University of California at San Diego, Preliminary Manuscript, January 1989. 
3 Jutel A., Lupton D. (2015) Digitizing diagnosis: a review of mobile applications in the diagnostic process. Diagnosis, vol. 2, no. 2, pp. 89-96.

4 Vasilenko, A. M. Komplementarnaya medicina: voprosy terminologii i klassifikacii: PDF // Rossijskij medicinskij zhurnal. - 2014. - T. 20, № 6. - S. 7-11. - UDK 615.89:001.4:005(G). [Vasilenko, A. M. Komplementarnaya medicina: voprosy terminologii i klassifikacii: PDF // Rossijskij medicinskij zhurnal. - 2014. - T. 20, № 6. - S. 7-11. - UDK 615.89:001.4:005(G).]

5 Bryson, A.E., and Ho, Yu-Chi, Applied Optimal Control, Blaisdell, New York, 1969.

6 Carpenter, Gail A., and Grossberg, Stephen, "A Massively Parallel Architecture for a Selforganizing Neural Pattern Recognition Machine",

7 Carpenter, Gail A., and Grossberg, Stephen, “ART 2: self-organization of stable category recognition codes for analog input patterns”, Applied Optics, 26, No.23, 4919-4930, 1 December 1987.

8 Carpenter, Gail A., and Grossberg, Stephen, 'Associative learning, adaptive pattern recognition, and cooperative-competitive decision making by neural networks", in Ssu, Harold (Ed.), Optical and Hybrid Computing, SPIE Institute Series, published as: SPIE Proc., 634, 218-247, 1986.

9 Cater, John, P.,'Successfully Using Peak Learning Rates of 10 (and Greater) in Back-Propagation Networks with the Heuristic Learning.

10 Allard R. Use of time-series analysis in infectious disease surveillance. Bull World Health Organ. 1998;76(4):327-33.

11 Allen B, Thorwarth WT. Comments from the American College of Radiology. Washington, DC: 2014. (Input submitted to the Committee on Diagnostic Error in Health Care, November 5 and December 29, 2014).

12 Oh JY, Bancroft JE, Cunningham MC, et al. Comparison of survey methods in norovirus outbreak investigation, Oregon, USA, 2009. Emerg Infect Dis. 2010;16:1773-6.

13 Langlois, John P. (2002). "Making a Diagnosis". In Mengel, Mark B.; Holleman, Warren L.; Fields, Scott A. (eds.). Fundamentals of Clinical Practice (2nd ed.). New York, N.Y.: Kluwer Academic/Plenum Publishers.

14 Jackson R, Dannenberg A, Frumkin H. Health and the Built Environment: 10 Years After. Am J Public Health. 2013 September;103(9):1542-44.

\title{
А. Н. АЖЕН, З. М. АБДИАХМЕТОВА, Б. К. АЛИМБАЕВА, М. К. БЕКБАЕВА
}

\author{
Әл-Фараби атындагы Қазақ ұлттық университеті, Алматы, Қазақсстан, \\ e-mail:azhen_ayazhan@mail.ru,zukhra.abdiakhmetova@gmail.com, \\ abaggi@mail.ru,maya.bekbayeva@gmail.com
}

\section{АДАМНЫН АУРУЫНЫН СИМПТОМЫН АНЫҚТАЙТЫН АКПАРАТТЫК ЖУЙЕНІ КҰРУ}

\begin{abstract}
Мақ̧алада аурудың симптомын анықттайтын ақпараттық жүйені құру құарастырылван. Ауруды анықтау барысында нейрондық жүйе қолданылды. Нейрондық желі кіріс қабаттан, 3 жасырын құабаттан және шызыс қ̧абаттан тұрады. Нейрондық жүйе толықтай жұмыс жасап, өте жогары результатар берді. Пайдаланушылардың құлдануына оңай болуы үшін, телеграм бот жасалынды. Телеграмм бот ақпараттық жүйенің барлық міндеттеріне сай және барльқ адамва қолжетімді болып табылады.
\end{abstract}

Түйін сөздер: жасанды интеллект, ақпараттық жүйе, тестілеу, Telegram Bot API, диагностика. 
А. Н. АЖЕН, З. М. АБДИАХМЕТОВА, Б. К. АЛИМБАЕВА, М. К. БЕКБАЕВА

Казахский национальный университет имени аль-Фараби, Алматы, Қазақсстан, e-mail:azhen_ayazhan@mail.ru,zukhra.abdiakhmetova@gmail.com, abaggi@mail.ru,maya.bekbayeva@gmail.com

\section{СОЗДАНИЕ ИНФОРМАЦИОННОЙ СИСТЕМЫ ОПРЕДЕЛЕНИЯ СИМПТОМОВ ЗАБОЛЕВАНИЙ ЧЕЛОВЕКА}

В статье предусмотрено создание информационной системы, которая выявляет симптомы заболевания. Нейронная система использовалась для диагностики болезни. Нейронная сеть со-стоит из входного слоя, 3 скрытых слоев и выходного слоя. Нейронная система была полностью работоспособной и дала очень высокие результаты. Бот для телеграмм был создан, чтобы упро-стить пользователям использование. Телеграмм- бот отвечает всем требованиям информацион-ной системы и доступен всем.

Ключевые слова: искусственный интеллект, информационная система, тестирование, Telegram Bot API, диагностика. 